\title{
Treatment of cellulite based on the hypothesis of a novel physiopathology
}

This article was published in the following Dove Press journal:

Clinical, Cosmetic and Investigational Dermatology

25 May $201 \mathrm{I}$

Number of times this article has been viewed

\author{
José Maria Pereira de \\ Godoy' \\ Maria de Fátima Guerreiro \\ de Godoy ${ }^{2}$ \\ 'Department of Cardiology and \\ Cardiovascular Surgery, \\ ${ }^{2}$ Lymphovenous Rehabilitation, \\ FAMERP, São José do Rio Preto, Brazil
}

Background: The aim of the current study is to report on a new form of treatment for cellulite based on a novel physiological hypothesis.

Methods: A novel treatment for cellulite was evaluated in 14 patients aged 19-36 (mean 27.5) years. The only inclusion criterion was clinically diagnosed cellulite, and the exclusion criteria were history of edema, obesity, or any other disease diagnosed during the physical examination. Perimetry was performed at the gluteal fold, at $5 \mathrm{~cm}$ and $10 \mathrm{~cm}$ below the gluteal fold for both legs, and $5 \mathrm{~cm}$ and $10 \mathrm{~cm}$ below the navel. Additionally, standard photographs were taken and a questionnaire of satisfaction was applied. The patients were submitted to a treatment regimen of 1.5 hours per day adapted for the treatment of cellulite, consisting of manual and mechanical lymph drainage and cervical stimulation using the Godoy and Godoy technique. After 10 sessions over two weeks, the patients were evaluated again.

Results: Reductions were identified at both points below the navel, the points on the thighs, and at the gluteal fold $(P<0.0001)$.

Conclusion: This technique of lymphatic system stimulation is efficacious in the treatment of cellulite.

Keywords: cellulite, treatment, physiopathology

\section{Introduction}

The presence of cellulite is an esthetically unacceptable cosmetic problem for most postadolescent women. ${ }^{1}$ Cellulite, or so-called "orange peel" skin affects $80 \%-90 \%$ of all females. It is not considered as a pathological condition but as esthetically disturbing dimpling of the skin, seen most commonly on the thighs and buttocks. ${ }^{2}$

Cellulite is an alteration of the topography of the skin that occurs in body areas where fat deposits seem to be under the influence of estrogen, mainly the hips, buttocks, thighs, and abdomen. There is currently no cure or consistently effective treatment for cellulite. ${ }^{3}$ In fact, no treatment is completely successful, and none are more than mildly and temporarily effective. ${ }^{4}$

This condition is not specific to overweight women, although increased adipogenicity will exacerbate the condition. It is a complex problem involving the microcirculatory system and lymphatics, the extracellular matrix, and the presence of excess subcutaneous fat that bulges into the dermis. ${ }^{1}$

There are glaring discrepancies regarding the microanatomical descriptions of this condition in the literature, ${ }^{5}$ and the pathophysiological aspects of cellulite are still not clear. ${ }^{6}$ Only a limited number of studies on cellulite have been published in the international literature, and many of them reach somewhat antithetical conclusions.

\author{
Correspondence: José Maria Pereira \\ de Godoy \\ Rua Floriano Peixoto, 2950, São José do \\ Rio Preto I5010-020, Brazil \\ $\mathrm{Tel} / \mathrm{Fax}+551732326362$ \\ Email godoyjmp@riopreto.com.br
}


Consequently, it is not yet possible to reconcile the extreme differences of opinion which have lingered for years concerning the nature of this disorder, as well as its origin and even the most basic aspects of its histopathological classification. ${ }^{7}$

There is no consensus in respect to the anatomical changes in cellulite and even less on a pathophysiological basis that can guide treatment. However, a series of proposals have been published. ${ }^{8-12}$

This suggests that cellulite is a consequence of alterations that develop in the lymphatic system and lead to an accumulation of substances in subcutaneous tissue, in particular in the cellular interstice. These alterations may be influenced by hormones or by any other mechanism that predisposes the individual to an accumulation of fluids and other substances in the cellular interstice. Thus stimulation, using appropriate techniques may be efficacious in the reduction of cellulite. ${ }^{13}$

The objective of the current study is to report on a novel form of treatment for cellulite based on a new pathophysiological hypothesis.

Table I Pre- and post-treatment measurements 5 and $10 \mathrm{~cm}$ below the navel

\begin{tabular}{|c|c|c|c|c|}
\hline $\begin{array}{l}\text { Patient } \\
\text { (n) }\end{array}$ & & $\begin{array}{l}\text { Pretreatment } \\
(\mathrm{cm})\end{array}$ & $\begin{array}{l}\text { Post-treatment } \\
(\mathrm{cm})\end{array}$ & $\begin{array}{l}\text { Difference } \\
(\mathrm{cm})\end{array}$ \\
\hline \multirow[t]{2}{*}{1} & $5 \mathrm{~cm}$ & 108 & 104 & 4 \\
\hline & $10 \mathrm{~cm}$ & 88 & 84 & 4 \\
\hline \multirow[t]{2}{*}{2} & $5 \mathrm{~cm}$ & 100 & 98 & 2 \\
\hline & $10 \mathrm{~cm}$ & 96 & 94 & 2 \\
\hline \multirow[t]{2}{*}{3} & $5 \mathrm{~cm}$ & 105 & 102 & 3 \\
\hline & $10 \mathrm{~cm}$ & 103 & 100 & 3 \\
\hline \multirow[t]{2}{*}{4} & $5 \mathrm{~cm}$ & 105.5 & 101 & 4.5 \\
\hline & $10 \mathrm{~cm}$ & 106 & 104 & 2 \\
\hline \multirow[t]{2}{*}{5} & $5 \mathrm{~cm}$ & 112.5 & 109 & 3.5 \\
\hline & $10 \mathrm{~cm}$ & 113 & 106 & 7 \\
\hline \multirow[t]{2}{*}{6} & $5 \mathrm{~cm}$ & 99.5 & 95 & 4.5 \\
\hline & $10 \mathrm{~cm}$ & 98 & 93 & 5 \\
\hline \multirow[t]{2}{*}{7} & $5 \mathrm{~cm}$ & 84.5 & 82 & 2.5 \\
\hline & $10 \mathrm{~cm}$ & 83 & 81.5 & 1.5 \\
\hline \multirow[t]{2}{*}{8} & $5 \mathrm{~cm}$ & 95 & 93 & 2 \\
\hline & $10 \mathrm{~cm}$ & 93 & 91 & 2 \\
\hline \multirow[t]{2}{*}{9} & $5 \mathrm{~cm}$ & 105 & 102.8 & 2.2 \\
\hline & $10 \mathrm{~cm}$ & 103 & 100 & 3 \\
\hline \multirow[t]{2}{*}{10} & $5 \mathrm{~cm}$ & 86.5 & 84 & 2.5 \\
\hline & $10 \mathrm{~cm}$ & 82 & 78.5 & 3.5 \\
\hline \multirow[t]{2}{*}{ II } & $5 \mathrm{~cm}$ & 105 & 103 & 2 \\
\hline & $10 \mathrm{~cm}$ & 103 & 99 & 4 \\
\hline \multirow[t]{2}{*}{12} & $5 \mathrm{~cm}$ & 100.5 & 97 & 3.5 \\
\hline & $10 \mathrm{~cm}$ & 98.5 & 94 & 4.5 \\
\hline \multirow[t]{2}{*}{13} & $5 \mathrm{~cm}$ & 98.9 & 95 & 3.9 \\
\hline & $10 \mathrm{~cm}$ & 96.5 & 94 & 2.5 \\
\hline \multirow[t]{3}{*}{14} & $5 \mathrm{~cm}$ & 99 & 96 & 3 \\
\hline & $10 \mathrm{~cm}$ & 103 & 98.7 & 4.3 \\
\hline & Mean & *98.9 & $* * 95.6$ & 3.3 \\
\hline
\end{tabular}

Note: $* P<0.0001$.
Table 2 Pretreatment and post-treatment measurements of the right thigh $5 \mathrm{~cm}$ and $10 \mathrm{~cm}$ below the gluteal fold

\begin{tabular}{|c|c|c|c|c|}
\hline $\begin{array}{l}\text { Patient } \\
\text { (n) }\end{array}$ & & $\begin{array}{l}\text { Pretreatment } \\
(\mathrm{cm})\end{array}$ & $\begin{array}{l}\text { Post-treatment } \\
(\mathrm{cm})\end{array}$ & $\begin{array}{l}\text { Difference } \\
(\mathrm{cm})\end{array}$ \\
\hline \multirow[t]{2}{*}{$\mathrm{I}$} & $5 \mathrm{~cm}$ & 57.6 & 54 & 3.6 \\
\hline & $10 \mathrm{~cm}$ & 55 & 52 & 3 \\
\hline \multirow[t]{2}{*}{2} & $5 \mathrm{~cm}$ & 53 & 51 & 2 \\
\hline & $10 \mathrm{~cm}$ & 51 & 49 & 2 \\
\hline \multirow[t]{2}{*}{3} & $5 \mathrm{~cm}$ & 54 & 51 & 3 \\
\hline & $10 \mathrm{~cm}$ & 51 & 48 & 3 \\
\hline \multirow[t]{2}{*}{4} & $5 \mathrm{~cm}$ & 61.5 & 57.5 & 4 \\
\hline & $10 \mathrm{~cm}$ & 59.5 & 55 & 4.5 \\
\hline \multirow[t]{2}{*}{5} & $5 \mathrm{~cm}$ & 63.5 & 61 & 2.5 \\
\hline & $10 \mathrm{~cm}$ & 60 & 57 & 3 \\
\hline \multirow[t]{2}{*}{6} & $5 \mathrm{~cm}$ & 55.8 & 50.5 & 5.3 \\
\hline & $10 \mathrm{~cm}$ & 53 & 48 & 5 \\
\hline \multirow[t]{2}{*}{7} & $5 \mathrm{~cm}$ & 46.5 & 42 & 4.5 \\
\hline & $10 \mathrm{~cm}$ & 43 & 41 & 2 \\
\hline \multirow[t]{2}{*}{8} & $5 \mathrm{~cm}$ & 55.5 & 53 & 2.5 \\
\hline & $10 \mathrm{~cm}$ & 54 & 52 & 2 \\
\hline \multirow[t]{2}{*}{9} & $5 \mathrm{~cm}$ & 60.3 & 55 & 5.3 \\
\hline & $10 \mathrm{~cm}$ & 56.8 & 53.5 & 3.3 \\
\hline \multirow[t]{2}{*}{10} & $5 \mathrm{~cm}$ & 45.8 & 43 & 2.8 \\
\hline & $10 \mathrm{~cm}$ & 49 & 45 & 4 \\
\hline \multirow[t]{2}{*}{11} & $5 \mathrm{~cm}$ & 62 & 60 & 2 \\
\hline & $10 \mathrm{~cm}$ & 58 & 56 & 2 \\
\hline \multirow[t]{2}{*}{12} & $5 \mathrm{~cm}$ & 54 & 52 & 2 \\
\hline & $10 \mathrm{~cm}$ & 49.6 & 47 & 2.6 \\
\hline \multirow[t]{2}{*}{13} & $5 \mathrm{~cm}$ & 58 & 55 & 3 \\
\hline & $10 \mathrm{~cm}$ & 58 & 54.2 & 3.8 \\
\hline \multirow[t]{3}{*}{14} & $5 \mathrm{~cm}$ & 52 & 49 & 3 \\
\hline & $10 \mathrm{~cm}$ & 47.5 & 44 & 3.5 \\
\hline & Mean & $* 54.4$ & $* * 51.2$ & 3.2 \\
\hline
\end{tabular}

Note: $* P<0.0001$.

\section{Methods}

A novel form of treatment for cellulite was evaluated in 14 patients aged 19-36 (mean 27.5) years. On acceptance, consecutive patients were enrolled in this study. The only inclusion criterion was clinically diagnosed cellulite, and the exclusion criteria were history of edema, obesity, or any other disease diagnosed during the physical examination. Perimetry was performed at the gluteal fold, at $5 \mathrm{~cm}$ and $10 \mathrm{~cm}$ below the gluteal fold for both legs, and $5 \mathrm{~cm}$ and $10 \mathrm{~cm}$ below the navel. Standard photographs were taken. The patients were submitted to a treatment regimen for 1.5 hours per day adapted for cellulite, consisting of manual and mechanical lymph drainage and cervical stimulation using the Godoy and Godoy technique. Thus, the treatment employed was an association of three techniques. Mechanical lymph drainage consists of the utilization of a device that causes passive plantar/dorsiflexion movements. ${ }^{14}$ The cervical stimulation technique was performed for 20 minutes per day. ${ }^{15,16}$ Manual lymph drainage was performed using manual compression 
of 30-40 mmHg. This subjectively determined pressure, as with conventional lymph drainage, is exerted with a sliding motion over the course of lymphatic collectors up to the corresponding lymph node regions. ${ }^{17,18}$

After 10 sessions over two weeks, the patients again underwent physical examination, including perimetry. Standard photographs were taken, and an investigation was made of the satisfaction of patients with the treatment results. The photographs were evaluated by two examiners who identified the differences between photographs. The greatest variation in the thigh and abdomen regions was considered for each patient.

The paired $t$-test was used for statistical analysis, with an alpha level of $5 \%(P<0.05)$ being considered significant. This study was approved by the research ethics committee of FAMERP.

\section{Results}

The mean circumferences at the points $5 \mathrm{~cm}$ and $10 \mathrm{~cm}$ below the navel were $98.9 \mathrm{~cm}$ and $95.6 \mathrm{~cm}$ before and after treatment,

Table 3 Pretreatment and post-treatment measurements of the left thigh $5 \mathrm{~cm}$ and $10 \mathrm{~cm}$ below the gluteal fold

\begin{tabular}{|c|c|c|c|c|}
\hline $\begin{array}{l}\text { Patient } \\
\text { (n) }\end{array}$ & & $\begin{array}{l}\text { Pretreatment } \\
(\mathrm{cm})\end{array}$ & $\begin{array}{l}\text { Post-treatment } \\
(\mathrm{cm})\end{array}$ & Difference \\
\hline \multirow[t]{2}{*}{$\mathrm{I}$} & $5 \mathrm{~cm}$ & 57 & 54 & 3 \\
\hline & $10 \mathrm{~cm}$ & 55 & 52 & 3 \\
\hline \multirow[t]{2}{*}{2} & $5 \mathrm{~cm}$ & 53.5 & 51 & 2.5 \\
\hline & $10 \mathrm{~cm}$ & 51.3 & 49 & 2.3 \\
\hline \multirow[t]{2}{*}{3} & $5 \mathrm{~cm}$ & 55 & 50.8 & 4.2 \\
\hline & $10 \mathrm{~cm}$ & 52 & 48 & 4 \\
\hline \multirow[t]{2}{*}{4} & $5 \mathrm{~cm}$ & 61 & 57 & 4 \\
\hline & $10 \mathrm{~cm}$ & 59.5 & 55 & 4.5 \\
\hline \multirow[t]{2}{*}{5} & $5 \mathrm{~cm}$ & 63 & 61 & 2 \\
\hline & $10 \mathrm{~cm}$ & 60.5 & 57 & 3.5 \\
\hline \multirow[t]{2}{*}{6} & $5 \mathrm{~cm}$ & 56 & 50.5 & 5.5 \\
\hline & $10 \mathrm{~cm}$ & 53 & 48 & 5 \\
\hline \multirow[t]{2}{*}{7} & $5 \mathrm{~cm}$ & 45.5 & 42 & 3.5 \\
\hline & $10 \mathrm{~cm}$ & 43.5 & 41.5 & 2 \\
\hline \multirow[t]{2}{*}{8} & $5 \mathrm{~cm}$ & 55 & 53 & 2 \\
\hline & $10 \mathrm{~cm}$ & 53.8 & 52 & 1.8 \\
\hline \multirow[t]{2}{*}{9} & $5 \mathrm{~cm}$ & 60 & 55 & 5 \\
\hline & $10 \mathrm{~cm}$ & 56.3 & 53.5 & 2.8 \\
\hline \multirow[t]{2}{*}{10} & $5 \mathrm{~cm}$ & 45.8 & 43 & 2.8 \\
\hline & $10 \mathrm{~cm}$ & 49.3 & 45 & 4.3 \\
\hline \multirow[t]{2}{*}{11} & $5 \mathrm{~cm}$ & 62 & 60 & 2 \\
\hline & $10 \mathrm{~cm}$ & 59 & 56 & 3 \\
\hline \multirow[t]{2}{*}{12} & $5 \mathrm{~cm}$ & 54 & 52 & 2 \\
\hline & $10 \mathrm{~cm}$ & 49 & 47 & 2 \\
\hline \multirow[t]{2}{*}{13} & $5 \mathrm{~cm}$ & 59.5 & 55 & 4.5 \\
\hline & $10 \mathrm{~cm}$ & 58 & 54 & 4 \\
\hline \multirow[t]{3}{*}{14} & $5 \mathrm{~cm}$ & 52 & 49 & 3 \\
\hline & $10 \mathrm{~cm}$ & 47 & 44 & 3 \\
\hline & Mean & $* 54.5$ & $* * 51.2$ & 3.5 \\
\hline
\end{tabular}

Note: $* P<0.0001$. respectively. Thus, the mean reduction with treatment was $3.3 \mathrm{~cm}$ (paired $t$-test: $P<0.0001$, Table 1 ). There were no significant differences between the initial measurements of the right and left thighs $(P=0.6)$. On the other hand, differences were seen between the measurements before $(54.4 \mathrm{~cm})$ and after $(51.2 \mathrm{~cm})$ treatment of the right thigh, with a mean loss of $3.2 \mathrm{~cm}(P<0.000$, Table 2$)$. Moreover, a significant difference of $3.5 \mathrm{~cm}$ was seen between pretreatment $(54.5 \mathrm{~cm})$ and posttreatment $(51.2 \mathrm{~cm})$ of the left leg $(P<0.0001$, Table 3$)$. The circumferences at the gluteal fold before and after treatment were $58.4 \mathrm{~cm}$ and $54.9 \mathrm{~cm}$, respectively, with a mean reduction of $3.5 \mathrm{~cm}(P<0.0001$, Table 4$)$. All the patients reported that they liked the results, and in the analysis of the photographs, both examiners were in agreement that the cellulite improved for 13 of the 14 patients (Figures 1 and 2).

\section{Discussion}

The current study demonstrates reductions in body measurements of regions in which the presence of clinical

Table 4 Pretreatment and post-treatment measurements at the gluteal fold

\begin{tabular}{|c|c|c|c|c|}
\hline $\begin{array}{l}\text { Patient } \\
\text { (n) }\end{array}$ & & $\begin{array}{l}\text { Pretreatment } \\
(\mathrm{cm})\end{array}$ & $\begin{array}{l}\text { Post-treatment } \\
\text { (cm) }\end{array}$ & Difference \\
\hline \multirow[t]{2}{*}{1} & $5 \mathrm{~cm}$ & 58 & 55 & 3 \\
\hline & $10 \mathrm{~cm}$ & 56 & 52 & 4 \\
\hline \multirow[t]{2}{*}{2} & $5 \mathrm{~cm}$ & 57 & 53 & 4 \\
\hline & $10 \mathrm{~cm}$ & 61.5 & 59 & 2.5 \\
\hline \multirow[t]{2}{*}{3} & $5 \mathrm{~cm}$ & 65 & 63 & 2 \\
\hline & $10 \mathrm{~cm}$ & 55.8 & 53 & 2.8 \\
\hline \multirow[t]{2}{*}{4} & $5 \mathrm{~cm}$ & 53 & 48 & 5 \\
\hline & $10 \mathrm{~cm}$ & 58 & 57 & I \\
\hline \multirow[t]{2}{*}{5} & $5 \mathrm{~cm}$ & 63.5 & 58 & 5.5 \\
\hline & $10 \mathrm{~cm}$ & 47 & 45 & 2 \\
\hline \multirow[t]{2}{*}{6} & $5 \mathrm{~cm}$ & 66 & 62.5 & 3.5 \\
\hline & $10 \mathrm{~cm}$ & 58 & 55 & 3 \\
\hline \multirow[t]{2}{*}{7} & $5 \mathrm{~cm}$ & 59.5 & 55 & 4.5 \\
\hline & $10 \mathrm{~cm}$ & 58.8 & 55 & 3.8 \\
\hline \multirow[t]{2}{*}{8} & $5 \mathrm{~cm}$ & 58.3 & 55 & 3.3 \\
\hline & $10 \mathrm{~cm}$ & 57 & 52 & 5 \\
\hline \multirow[t]{2}{*}{9} & $5 \mathrm{~cm}$ & 56.5 & 53 & 3.5 \\
\hline & $10 \mathrm{~cm}$ & 61.5 & 59 & 2.5 \\
\hline \multirow[t]{2}{*}{10} & $5 \mathrm{~cm}$ & 65 & 63 & 2 \\
\hline & $10 \mathrm{~cm}$ & 56 & 53 & 3 \\
\hline \multirow[t]{2}{*}{ II } & $5 \mathrm{~cm}$ & 52.5 & 48 & 4.5 \\
\hline & $10 \mathrm{~cm}$ & 58.5 & 56 & 2.5 \\
\hline \multirow[t]{2}{*}{12} & $5 \mathrm{~cm}$ & 63.8 & 58 & 5.8 \\
\hline & $10 \mathrm{~cm}$ & 47 & 45 & 2 \\
\hline \multirow[t]{2}{*}{13} & $5 \mathrm{~cm}$ & 66 & 62 & 4 \\
\hline & $10 \mathrm{~cm}$ & 58.5 & 55 & 3.5 \\
\hline \multirow[t]{3}{*}{14} & $5 \mathrm{~cm}$ & 60 & 55 & 5 \\
\hline & $10 \mathrm{~cm}$ & 59 & 55 & 4 \\
\hline & Mean & $* 58.4$ & $* * 54.9$ & 3.5 \\
\hline
\end{tabular}

Note: $* P<0.0001$. 

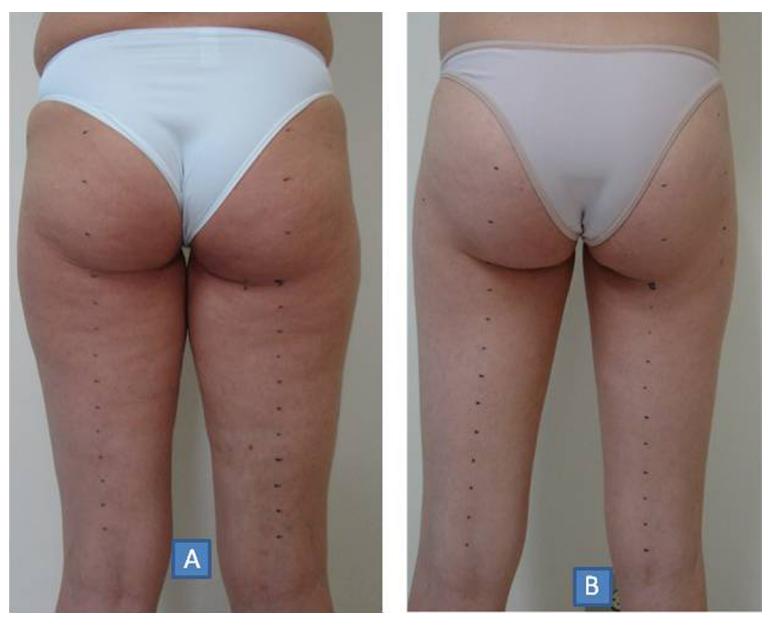

Figure IA and IB. Pretreatment and post-treatment of the gluteal fold and thighs.

cellulite was detected. The satisfaction of the patient in respect to treatment, regional volumetric reductions, and improvement in the clinical evaluation, all substantiate the efficacy of this new option of treatment for cellulite.

This novel approach was developed from clinical observations that cellulite normalized with lymphedema treatment that

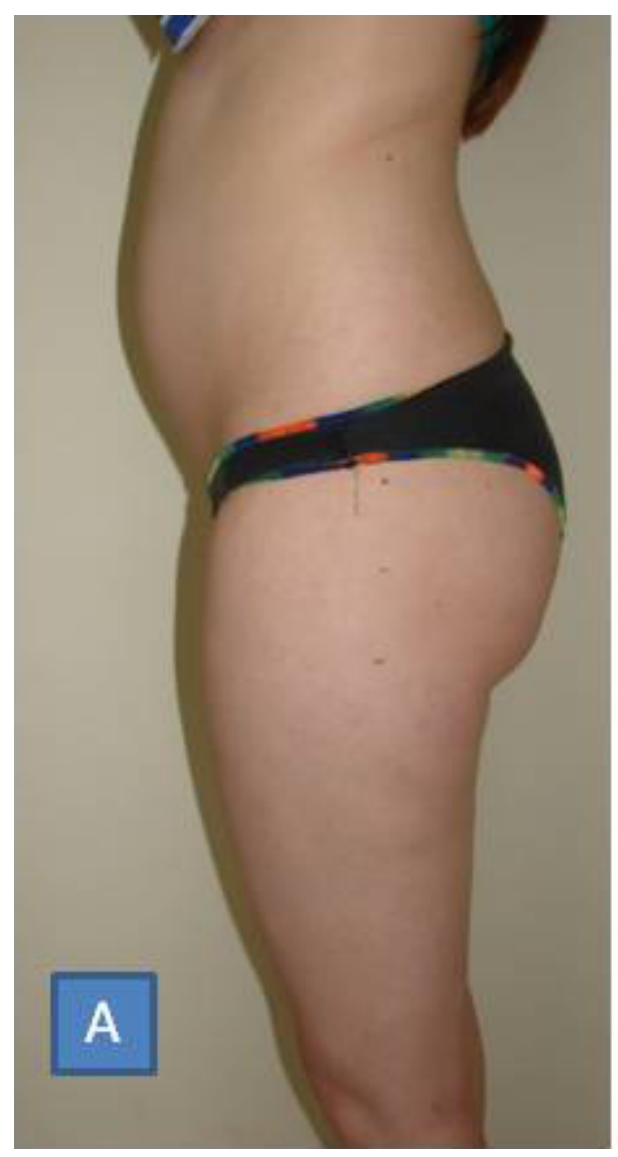

utilizes specific techniques of manual and mechanical lymph drainage. From these findings, studies of the pathophysiological basis of the condition were made in an attempt to explain the results. ${ }^{13}$ However, there is no consensus in the literature about the pathophysiology of cellulite. ${ }^{19-21}$ Subsequently, published histological data were analyzed which also did not demonstrate a consensus. However, modifications of the interstice matrix suggest that a physiological hypothesis should explain these changes in the lymphatic system..$^{20,21}$

Only lean women with cellulite were enrolled in this study to eliminate any interference of obesity. Another precaution was to exclude patients with idiopathic cyclic edema and other forms of clinically evident edema. Thus, two important causes of accumulation of fluids and other substances in the subcutaneous tissue were excluded.

The three conditions, ie, edema, cellulite, and obesity, can occur simultaneously. However, the treatment should be specific for each condition; if not, the objective of treatment will not be reached. This association of conditions leads to increases in alterations of subcutaneous tissue, and so has a synergic effect, both to aggravate the symptoms and improve

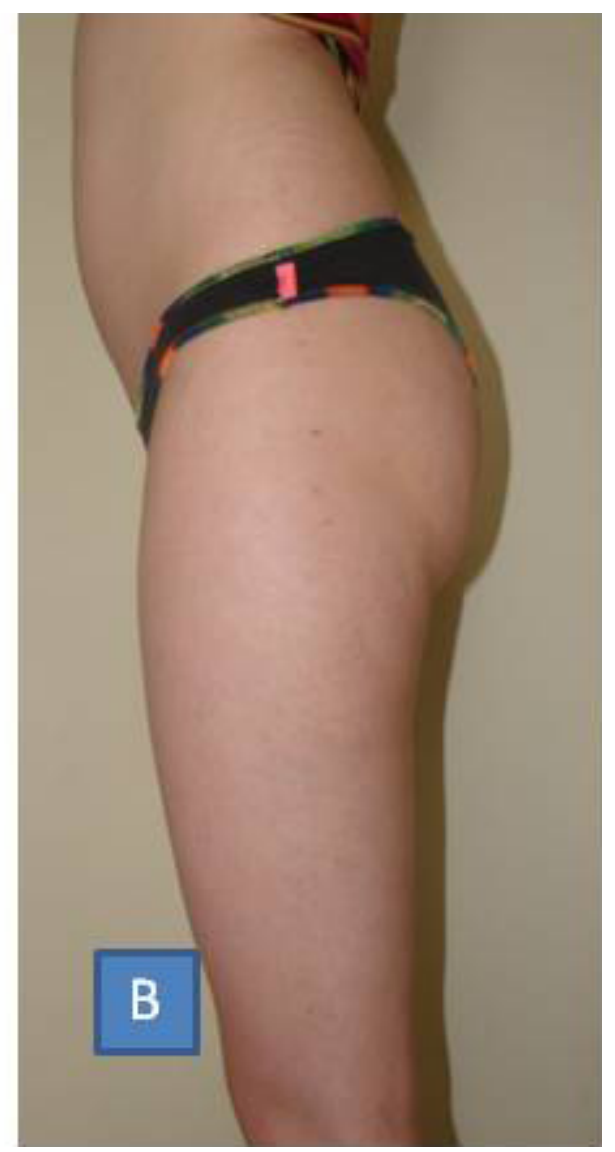

Figure 2A and 2B. Pretreatment and post-treatment $5 \mathrm{~cm}$ and $10 \mathrm{~cm}$ below the navel. 
the treatment. This we denominated the cellulitic complex to facilitate the diagnosis and guide the therapeutic conduct.

The basis of treatment in this study was to stimulate both the deep and superficial lymphatic system. This approach included cervical stimulation which, the authors believe, stimulates contraction and motility of lymphatic vessels. ${ }^{15,16}$ This drainage technique was developed by the authors, and is based on physiology, anatomy, pathophysiology, and hydrodynamic concepts consistent with reproducible scientific principles both in vitro and in vivo. Hence, all the movements utilized in this lymph drainage technique follow scientific principles based on hemodynamic concepts for fluid drainage in collectors. An in vivo study can be reproduced using dyes while draining the lymphatic collectors of animals or by using lymphoscintigraphy.

Reduction in cellulite can be total, and no further reduction in the circumferences occurs. Moreover, reductions were only observed in the regions where cellulite was detected; the worse the cellulite, the better the results. It is possible to reduce the perimeter at the point of greatest diameter in 10 sessions without the patient losing weight. Thus, these results show that cellulite (regional cutaneous lymphostasis) has its own physiopathology which is totally different from that for obesity and edema.

We have been studying this technique for 10 years, and have seen that results can be maintained for years, as long as the patient does not put on weight or present with edema, so the results are long-lasting. This technique is a novel approach to the treatment of cellulite, involving stimulation of the physiological processes of the body, and so it is the body itself that re-establishes its equilibrium. In conclusion, this lymphatic system simulation technique is efficacious in the treatment of cellulite.

\section{Disclosure}

The authors report no conflicts of interest in this work.

\section{References}

1. Rawlings AV. Cellulite and its treatment. Int J Cosmet Sci. 2006;28: $175-190$.
2. Pavicic T, Borelli C, Korting HC. Cellulite - the greatest skin problem in healthy people? An approach. J Dtsch Dermatol Ges. 2006;4: 861-870. German.

3. Goldman A, Gotkin RH, Sarnoff DS, Prati C, Rossato F. Cellulite: A new treatment approach combining subdermal Nd:YAG laser lipolysis and autologous fat transplantation. Aesthet Surg J. 2008;28: 656-662.

4. Wanner M, Avram M. An evidence-based assessment of treatments for cellulite. J Drugs Dermatol. 2008;7:341-345.

5. Quatresooz P, Xhauflaire-Uhoda E, Piérard-Franchimont C, Piérard GE Cellulite histopathology and related mechanobiology. Int J Cosmet Sci. 2006;28:207-210.

6. Rona C, Carrera M, Berardesca E. Testing anticellulite products. Int $J$ Cosmet Sci. 2006;28:169-173.

7. Terranova F, Berardesca E, Maibach H. Cellulite: Nature and aetiopathogenesis. Int J Cosmet Sci. 2006;28:157-167.

8. Van der Lugt C, Romero C, Ancona D, Al-Zarouni M, Perera J, Trelles MA. A multicenter study of cellulite treatment with a variable emission radio frequency system. Dermatol Ther. 2009;22:74-84.

9. Lach E. Reduction of subcutaneous fat and improvement in cellulite appearance by dual-wavelength, low-level laser energy combined with vacuum and massage. J Cosmet Laser Ther. 2008;10:202-209.

10. Sasaki GH. Comparison of results of wire subcision performed alone, with fills, and/or with adjacent surgical procedures. Aesthet Surg J. 2008;28:619-626.

11. Christ C, Brenke R, Sattler G, Siems W, Novak P, Daser A. Improvement in skin elasticity in the treatment of cellulite and connective tissue weakness by means of extracorporeal pulse activation therapy. Aesthet Surg J. 2008;28:538-544.

12. Pires-de-Campos MS, Leonardi GR, Chorilli M, Spadari-Bratfisch RC, Polacow ML, Grassi-Kassisse DM. The effect of topical caffeine on the morphology of swine hypodermis as measured by ultrasound. $J$ Cosmet Dermatol. 2008;7:232-237.

13. De Godoy JM, de Godoy M de F. Physiopathological hypothesis of cellulite. Open Cardiovasc Med J. 2009;3:96-97.

14. Godoy JMP, Godoy MFG. Development and evaluation of a new apparatus for lymph drainage: Preliminary results. Lymphology. 2004;37:62-64.

15. Godoy JMP, Godoy MFG. Godoy and Godoy technique of cervical stimulation in the reduction of edema of the face after cancer treatment. QJM. 2008;101:325-326.

16. Pereira de Godoy JM, Silva SH, Toninato MC, Godoy M de F. Cervical stimulation for volumetric reduction of limbs in the treatment of lymphedema. Indian J Med Sci. 2008;62:423-425.

17. Godoy JMF, Godoy MFG, Batigalia F. Preliminary evaluation of a new, more simplified physiotherapy technique for lymphatic drainage. Lymphology. 2002;35:91-93.

18. Godoy JMP, Godoy MFG. Manual lymph drainage: A new concept. J Vasc Br. 2004;3:77-80.

19. Alquier L. Ce qu'est la cellulite. Comment la traiter. Monde Med. 1949;59:344.

20. Segers AM, Abulafia J, Kriner J, Cortodono O. Cellulitis. Histopathologic and histochemical study of 100 cases. [Article in Spanish]. Méd Cutan Ibero Lat Am. 1984;12:167-172.

21. Fernandéz G, Curri SB. Venous stasis and panniculopathy: a semiologic study. Angiologia [Article in Spanish];1990:42:127-132.
Clinical, Cosmetic and Investigational Dermatology

\section{Publish your work in this journal}

Clinical, Cosmetic and Investigational Dermatology is an international, peer-reviewed, open access, online journal that focuses on the latest clinical and experimental research in all aspects of skin disease and cosmetic interventions. All areas of dermatology will be covered; contributions will be welcomed from all clinicians and

\section{Dovepress}

basic science researchers globally. This journal is indexed on CAS. The manuscript management system is completely online and includes a very quick and fair peer-review system, which is all easy to use. Visit http://www.dovepress.com/testimonials.php to read real quotes from published authors. 